\title{
Unit of Mass
}

National Cancer Institute

\section{Source}

National Cancer Institute. Unit of Mass. NCI Thesaurus. Code C42579.

An indication of the type of unit of measure being used to express a mass. 